ISSN: $1782-2041$

DOI: $10.25518 / 1782-2041.1256$

\title{
The Rationalization of Consciousness: A Mereological Reconstruction of Husserl's Fifth Logical Investigation
}

\author{
ALEXIS DELAMARE \\ Université de Rouen/ERIAC - Universität Heidelberg \\ $\triangle$ alexis.delamare5@univ-rouen.fr
}

\begin{abstract}
Before engaging with intentionality, the philosopher of mind must consider the intrinsic nature of psychological elements. Conscious states, contrary to ordinary and scientific objects, seem to penetrate each another in such a way that it becomes impossible to enumerate, class or organize through laws the various experiences at stake. In this context, how is a science of consciousness conceivable? How is it possible to apply the epistemological requirements of any science to a domain whose ontological nature contradicts such demands? The paper reconstructs Husserl's solution to this issue in the Fifth Logical Investigation. I show how his appeal to the mereological framework of the Third Investigation gives him the tools to rationalize the domain of the mind and to establish phenomenology as an authentic science of consciousness. I first demonstrate that the very task of phenomenological investigations is defined in mereological terms. I then reconstruct the issue regarding the inclusion of the intentional object within the act, by exposing the nuances of the Husserlian position in this famous controversy. In a last part, I show how mereological concepts are at the core of the Husserlian reinterpretation of the Brentanian thesis according to which all acts are presentations or based on presentations.
\end{abstract}

Keywords Husserl, Logical Investigations, mereology, intentionality, Twardowski, Brentano, noema, transcendental reduction. 


\section{Introduction}

The theme of consciousness has been at the center of the philosophical debates since Descartes. One of the main disputed issues concerns its relationship with external objects. Yet, even before engaging with this relative issue, another, more primitive problem, is at stake for the philosopher of mind. It pertains to the very nature of the elements constituting the field of consciousness, independently from any considerations regarding their 'intentionality'. Bergson's distinction between "two kinds of multiplicities" (Bergson 2001, p. 121) is of great help to formulate the issue at play. In addition to the "quantitative multiplicity' that accounts for 'juxtapositions' of elements, Bergson emphasizes the existence of "qualitative multiplicities" (Bergson 2001, p. 121). The états de conscience belong to the latter category. Sensations, emotions, judgements "may be compared to a living being, whose parts, although distinct, permeate one another just because they are so closely connected" (Bergson 2001, p. 100). This is what Bergson famously called "true duration" (Bergson 2001, p. 108), which is betrayed as soon as psychic states are understood in the framework of a quantitative model, in particular in language, which spatializes those états de conscience.

These Bergsonians considerations on the special ontological status of psychological elements have massive consequences for Husserl's phenomenology. ${ }^{1}$ As is well-known, Husserl's purpose, inherited from Brentano, ${ }^{2}$ is to raise philosophy to the status of a science, as the very title of the 1911 essay, Philosophie als strenge Wissenschaft, reveals. This ambition relies essentially on the possibility of a scientific treatment of consciousness - yet, there are at

\footnotetext{
${ }^{1}$ Let's recall that Husserl felt very close to Bergson, in particular regarding the flux of consciousness (Godani 2010; Winkler 2006). He is reported to have declared, in 1917, after having listened to the developments dedicated to the durée pure in Ingarden's thesis (Ingarden 1922), that "it is just like I am Bergson" (Ingarden and Husserl 1968, p. 121). Around 1911, when he first learnt about Bergson, he stated that "we are the consistent Bergsonians" (Hering 1939, p. 368). In addition, he sent an exemplar of the Ideen I to Bergson in 1913 (Husserl 1994a, p. VI, 11).

${ }^{2}$ In his Habilitation (1866), Brentano wrote (first thesis): "It is important for philosophy to protest against the division of science into exact and speculative sciences; this protest is the reason for its existence" (Brentano 2013, p. 136). According to Husserl, Brentano thus had "the intimate certitude to be on the right path and to establish the only scientific philosophy" (Kraus 1919, p. 160). See (Gilson 1966, p. 418; Huemer 2018; Ingarden 1969, p. 460).
} 
least four minimal criteria of scientificity (Prolegomena, §6) that seem to become inapplicable if we are to follow Bergson's arguments on the nature of lived experiences:

1) First, the elements of a scientific domain must be clearly distinct. 1 is not 2, a neutron is not a proton. Yet, all elements of consciousness seem to interpenetrate each other.

2) Second, these elements must not be considered in their individuality, but always as representants of classes. A token (for instance, a virus) owes its proprieties to its type (the virus type). Yet, mental experiences seem unique, unrepeatable.

3) Third, the domain at stake must be governed by laws, that apply to these classes, and express the regularities in the succession or the structures of the phenomena in question. Yet, psychic states do not seem to obey any deterministic laws.

4) Fourth, these laws must be verbalized, so as to raise them to "an abiding possession of science" (Introduction to the Second Volume, p. 3 [I, p. 166]). ${ }^{1}$ Yet, language seems incapable to be truthful to our psychic experiences.

In this perspective, how is a science of consciousness, depicted in particular in the Fifth Logical Investigation, conceivable? How is it possible to apply what is epistemologically required in order to erect any science to a domain whose ontological nature is precisely in contradiction with such requirements?

Many of the French phenomenologists after Husserl seem to have chosen to place the emphasis on the ontological side of the issue at the expense of the epistemological requirements. The scientific apprehension of our "chair" (Merleau-Ponty) or our "vie" (Henry) misses its essence. Hence, the descriptive task of phenomenology implies the "the disavowal of science" ("le désaveu de la science") (Merleau-Ponty 1945, p. 11). ${ }^{2}$

Yet another path, that maintains a balance between the epistemological and the ontological sides of the dilemma, is actually possible, and was initiated by Husserl himself. As I intend to show, the most important instrument that helped Husserl dealing with such challenge is his mereology, that is, the theory

\footnotetext{
${ }^{1}$ References to the Logical Investigations (abridged $L I$ ) will be displayed as follows: the number of the Investigation followed by the page number of the second edition (Husserl 1913a, 1913b, 1921), with the corresponding volume and page of the English translation by Findlay (Husserl 2001) in bracket. The English translations provided will be Findlay's, except when explicitly stated.

${ }^{2}$ See (Henry 2011, pp. 620-621, 2012, p. 14) for similar developments.
} 
of parts and wholes, of dependence and foundation, that he developed in the $3^{r d} L I$. Both the $3^{r d} L I^{1}$ and the $5^{\text {th }} L I^{2}$ have already received a great deal of attention in the literature, yet their relationship has not been sufficiently emphasized, since no exhaustive account of the mereological dimension of the latter has been undertaken. ${ }^{3}$ I will try and close this gap by showing that the main themes and theses of the Fifth Investigation do require the conceptual apparatus built by the Third. ${ }^{4}$

In so doing, two issues are at play. First, Husserl's application of mereology to mental acts provides an insightful attempt to rationalize the domain of lived experiences. Mereology is indeed not a mere chapter of formal ontology. Rather, it constitutes the language used by the phenomenologist so as to transform her initially fluctuating, ineffable experiences into scientific knowledge. The other issue, peculiar to Husserl, is to highlight the unitary character of the Logical Investigations, which is not patent prima facie.

The paper is divided in three parts. In the first one, I aim at showing that the very task of phenomenological investigations is defined in mereological terms. I then reconstruct the issue regarding the inclusion of the intentional object within the act, and I expose the nuances of the Husserlian position in this famous controversy. In the third and last part, I show how mereological concepts are at the core of Husserl's reinterpretation of Brentano's thesis according to which all acts are presentations or based on presentations.

\section{The methodology of phenomenology}

\subsection{Phenomenology, an ideal science of consciousness}

The Fifth Investigation is officially presented as an attempt to clarify the concept of (mental) "act" which is, according to Husserl, the most controversial term in descriptive psychology ( $5^{\text {th }} L I$, p. 340 [II, pp. 79-80]).

\footnotetext{
${ }^{1}$ See for instance (Casari 2007; Sokolowski 1968; Willard 2003).

2 See e.g. (Benoist 2001; Cobb-Stevens 2003; Erhard and Mayer 2008; Lorca 1999; Melle 1990; Q. Smith 1977; Sussbauer 1995; Zahavi 2008, Chapter V).

${ }^{3}$ Some insights in this direction can be found in (B. Smith 2000, p. 299; Sokolowski 1968, p. 453, 1974, p. 8; Sussbauer 1995, Chapter 2).

${ }^{4}$ It must be noted that this application of the $3 r d L I$ to the 5 th is far from an isolated case. Actually, the mereological science depicted in Zur Lehre von den Ganzen und Teilen owes much of its worth to the diversity of its material uses. On this question, see my work "The Power of Husserl's Third Logical Investigation", to appear in the next issue of Studia Phonomenologica.
} 
This task is achieved through a double shift in perspective. The phenomenologist must first stop considering the objects - as is done in ordinary life - and begin to focus on the acts in which they appear. This is what Husserl calls "reflection"" (Introduction to the Second Volume, p. 9 [I, p. 170]). Yet to this reflexive turn, a second one must be added, namely the eidetic turn: acts must not be seized as hic et nunc occurrences, as psychological events, but as exemplars, as instances of ideal species ( $5^{\text {th }} L I$, p. 368 [II, p. 96]), through the process of ideation $\left(5^{\text {th }} \mathrm{LI}\right.$, p. 369 [II, p. 97]). ${ }^{2}$ These two shifts in focus constitute the basis of Husserl's phenomenological methodology in the Logical Investigations.

How is this ideal study of acts to be accomplished? It is first necessary to exhibit the generic feature of acts, then to propose a description of the subspecies that divide this genus. Husserl emphasizes that such a classification must be achieved in an a priori manner: the grouping of such-and-such subtypes of acts under the same species must not rest on empirical resemblance, on mere coincidental occurrences. Any classification must on the contrary be founded on a priori, essential properties.

This rather abstract requirement is immediately illustrated through the analysis of intentionality. This latter is presented by Husserl as the generic characteristic of acts: "in perception something is perceived, in imagination, something imagined, in a statement, something stated, in love something loved, in hate hated, in desire desired, etc." ( $5^{\text {th }} L I$, p. 366 [II, p. 95]). It is wellknown that Husserl borrows the concept of intentionality from Brentano (Brentano 1974, pp. 124-128; Morrison 1970; Spiegelberg 1981), yet it must be firmly emphasized that, for Husserl, as opposed to Brentano, not all lived experiences (Erlebnisse) are intentional (Fisette 2011). For Brentano indeed, intentionality defines the realm of the psychological, by contrast with the physical. For Husserl, by contrast, intentionality defines a genus of experiences precisely the ones that are 'directed' towards an object ( $5^{\text {th }} L I$, p. 368 [II, p. 96]). This implies that some Erlebnisse lack intentional reference $\left(6^{\text {th }} L I\right.$, p. 242 [II, p. 348]). Examples are given by "sensations" (Empfindungen) $\left(5^{\text {th }}\right.$ $L I$, p. 369 [II, p. 97]) such as "rough or smooth, red or blue" $\left(5^{\text {th }} L I\right.$, p. 392 [II,

\footnotetext{
${ }^{1}$ Here Husserl builds on Brentano's internal perception (Brentano 1973, p. 40), against Natorp's objections (Natorp 1888, p. 13; Seron 2009; $5^{\text {th }} L I$, p. 360 [II, pp. 91-92]), even though his conception of an eidetic reflection was alien to Brentano's empirical descriptive psychology.

${ }^{2}$ In the second edition of the $L I$, this second turn is what distinguishes phenomenology from (descriptive) psychology. The psychologist never leaves the sphere of reality $\left(5^{\text {th }}\right.$ $L I$, p. 369 , n. 2; p. 398 [II, p. 353; p. 112]). See also the Introduction to the second volume (pp. 18-19 [I, pp. 175-176]).
} 
p. 109]); or by what Husserl calls "Gefühlsempfindungen", "affective sensations" such as the pain of a burn (id.). These sensations are purely and simply 'experienced' and have no 'aboutness'.

Once the generic character of all acts is established, Husserl goes on by depicting the different sub-species that can be displayed within this genus. Such species are for instance 'mere presentation', 'judgment', 'surmise', 'doubt', 'hope', 'fear', 'approval', 'desire' (5 $5^{\text {th }} L I$, p. 367 [II, p. 96]). ${ }^{1}$

Yet such a classificatory purpose is only preliminary: it provides the 'map', so to speak, of acts, but says nothing about the laws that govern them. Since, after the eidetic turn, only ideal relations are at stake, these laws cannot consist in inductive or predictive rules, that connect empirical occurrences of acts. Such principles, however precise, cannot be a priori. What is then left? The laws in question must be laws of structure. ${ }^{2}$ They do not pertain to the causal succession of experiences, ${ }^{3}$ but to the connections of essence ( $\mathrm{We}$ senszusammenhänge) ( $5^{\text {th }} L I$, p. 398 [II, p. 112]) between their species, that must hold for any instances of the latter. The task of phenomenology is thus understood as elucidating the "structures of essence of pure experiences" (Introduction to the Second Volume, p. 21 [I, p. 178]).

\subsection{Phenomenology investigates the structure of consciousness}

Such a structural elucidation is, according to Husserl, essentially mereological - that is, appeals to the concepts and results of the $3^{\text {rd }} L I$. A passage of the $2^{\text {nd }}$ $L I$ already reveals this fundamental relationship between mereology and the science of consciousness. Dealing with Hume and the "radical interpretation" $\left(2^{\text {nd }} L I, \S 37\right)$ of his theory of abstraction, Husserl asserts that such a perspective leads to a skepticism that pertains eventually to the very existence of parts. Here are the consequences of such a 'mereological skepticism':

\footnotetext{
${ }^{1}$ These sub-species are not the most primitive ones: the first division of acts is between objectifying and non-objectifying acts. More on this below p. 14.

${ }^{2}$ On this concept, see also Phenomenological Psychology: "'Structure' designates the complex intertwining which belongs to every concrete phase of the streaming psychic life" (Husserl 1977, p. 6).

${ }^{3}$ On this point Husserl follows Brentano's distinction between genetic and descriptive psychology (Brentano 1982, p. 1). Phenomenology does not study the causal relations between acts, but their inner structure: it is an Aufklärung, not an Erklärung, of lived experiences ( $2^{\text {nd }} L I$, p. 120 [I, p. 246]).
} 
If we persist in the skeptical direction, we shall have to doubt whether there are parts of any sort; and in consequence whether there is even a plurality of concrete contents, since ultimately (if we may still presume to judge the matter) the contents which appear in co-existence and succession are always in a manner unified. Our skepticism would at length be crowned by the assertion: consciousness is something quite unitary, regarding which we can at least not know, whether it has partial contents at all, or whether it in any way unfolds itself in simultaneous or temporally successive experiences.

Such a skepticism, it is plain, would render all psychologies impossible ( $2^{\text {nd }} L I$, p. 205 [I, p. 301]).

Husserl thus stresses that the mereological analysis of consciousness is a requirement for any psychological investigation. This the case not only for empirical psychology, but also for phenomenology understood as the pure science of consciousness.

This insight is fully developed in the $5^{\text {th }} L I$. Mereological concepts first appear, in this Investigation, as applied to the relationship between acts and the flux ${ }^{1}$ of consciousness. Every act is indeed an experience: in this respect, it belongs to the inner life of a subject. Yet such life is not a mere aggregate or jungle of experiences. Rather, it is organized by the total order relation that is called time (Sussbauer 1995, p. 62): each act occurs either before or after another act of the same subject. Therefore, acts cannot exist in an isolated fashion, they cannot occur except as a part of the whole stream of consciousness.

This 'intuitive' idea can be rigorously formulated via two mereological theses. On the one hand, acts are not concrete objects, that is, following the terminology of $3^{\text {rd }} L I$, objects that can exist on their own: they are in need of supplementation, "ergänzungsbedürftig" ( $3^{r d} L I$, p. 361 [II, p. 25]). This is made explicit in the Ideen I (Husserl 1982, p. 198) and in the 1905 lectures on time, where Husserl clearly appeals to the concepts of dependence and abstraction that he built in the $3^{\text {rd }} L I$ :

We know that the running-off phenomenon is a continuity of constant changes. This continuity forms an inseparable unity, inseparable into extended sections that could exist by themselves and inseparable into phases that could exist by themselves, into points of the continuity. The parts that we single out by abstraction can exist only in the whole running-off (Husserl 1991, p. 29).

\footnotetext{
${ }^{1}$ Husserl inherits this notion from James' Principles of Psychology. See (Leclerq and Galetic 2012).
} 
On the other hand, Husserl emphasizes that consciousness ${ }^{1}$ is an authentic unity. Again, consciousness has been defined in the $3^{\text {rd }} L I$ : a unity is a whole, that is, "a range of contents which are all covered by a unitary foundation without the help of further contents" ( $3^{\text {rd }} L I$, pp. 275-276 [II, p. 34, trans. modified]). This definition applies to consciousness (Sussbauer 1995, p. 72), since the contents that are required for an act to exist are precisely these other contents that belong to the same mental life. In the $L I$, Husserl identifies this unitary foundation with the ego, ${ }^{2}$ which is nothing but the "unitary sum total of contents" constituted by the "interconnected unity" of experiences $\left(5^{\text {th }} L I\right.$, pp. 353-354 [II, p. 86, trans. modified]). lated:

From these observations, three mereological propositions can be formu-

Proposition 1:

Consciousness is a unity, that is, an authentic whole.

Proposition 2:

Contents of consciousness, and in particular acts, are only abstract parts of this whole: they cannot exist apart from the flux to which they belong.

\section{Proposition 3:}

The ego is not a part of the flux; rather, it is only the flux itself understood as the unitary foundation of all its parts.

\subsection{The two purposes of Husserl's theory of consciousness}

It must nevertheless be noted that Husserl is not very rigorous in his terminology. He indeed talks of concrete contents of consciousness. A perception, for instance, is said to be a "full concrete act" (p. 383 [II, p. 104]). ${ }^{3}$ Is it not a contradiction? I do not think so. Husserl actually appeals (though implicitly) to a distinction forged in the $3^{\text {rd }} L I$, namely the one between absolute and relative dependence $\left(3^{\text {rd }} L I, \S 13\right)$. An object is said to be independent relatively

\footnotetext{
${ }^{1}$ It is precisely the first meaning of consciousness that is here at stake among the three depicted by Husserl. See $5^{\text {th }} L I, \S 1-2$, with the very important additions of the second edition on the purely phenomenological meaning of the concept of "experience" $\left(5^{\text {th }}\right.$ $L I$, p. 348 [II, p. 82]).

${ }^{2}$ As he explicitly states in the second edition, Husserl changed his mind regarding the issue of pure ego between 1901 and 1913. See (Marbach 1974) for details.

${ }^{3}$ Examples actually pervade the $5^{\text {th }}$ LI. See e.g. p. 349 [II, p. 83], p. 394 [II, p. 110].
}

\section{8}

Bull. anal. phén. XVII 4 (2021)

https://popups.uliege.be/1782-2041/ @ 2021 ULiège BAP 
to a given whole if the latter does not contain any of its required foundation hence a piece of extension, though dependent in an absolute fashion, is relatively independent to any other piece of extension.

Drawing on this definition, one may suggest the following classification of experiences: there are first experiences that are not dependent on other particular experiences. Let's call them self-sufficient experiences. For instance, the perception of a tree that I have now is not dependent on the imagination of Paris that I had two days ago. Actually, to perform this perception, I do not need to perform any other kind of experiences. Hence perceptions are only founded on the structure of the flux as such, but not on peculiar contents of the latter. Such is not the case, according to Husserl, for affective experiences like joy. A joy is only a 'layer' that must have a judgment (or any other positing 'objectifying act' ${ }^{\text {' }}$ ) at its base ( $5^{\text {th }} L I$, p. 404, [II, p. 116]): it is thus dependent on a particular content. It is this distinction that allows Husserl to speak of concrete ('self-sufficient') and abstract ('non self-sufficient') parts of consciousness.

The distinction is of considerable import for the $5^{\text {th }} L I$. The first purpose of this Investigation is precisely to determine which experiences can exist 'on their own', and which can only exist as being founded on others. ${ }^{2}$ This task must be fulfilled using only a priori laws, and thus presupposes the ideal classification of experiences into genus and species.

Yet this first issue can actually be generalized. In an act of joy, the affective 'layer' is supported by the founding judgment. They do not form a mere juxtaposition of acts, rather they make one, unique act: the joy taken to the state of affairs ( $i d$.$) . The same situation in fact holds for the state of affairs$ itself. If I judge that 'the knife is on the table', this act is composed of several parts. Yet those parts are so arranged that they form one new act $\left(5^{\text {th }} L I\right.$, p. 404, [II, p. 115]). Here Husserl appeals again to the definition of unity forged in the $3^{r d} L I$, yet applied, not to the flux of consciousness, but to particular experiences. ${ }^{3}$

As a result, the central issues that Husserl investigates in his science of acts - Which acts are abstract/concrete? Under which conditions can distinct

\footnotetext{
${ }^{1}$ More on this later, p. 12.

${ }^{2}$ As Smith and Mulligan aptly formulate it, "the project of Husserlian phenomenology can itself be described as being that of uncovering [...] the various families of dependence structures involving consciousness" (Mulligan and Smith 1988, p. 154).

${ }^{3}$ Husserl thus engages with what Van Inwagen (1987, p. 23) has later called the "Special Composition Question", applied to mental acts.
} 
acts come together to form a new act? - are mereological in their essence. The methodology of Husserl's phenomenology is his mereology.

I will now try to analyze two peculiar issues that, on the one hand, lie at the heart of the problems treated by Husserl in the $5^{\text {th }} L I$, and, on the other hand, can only be solved by appealing to mereological considerations.

\section{The first mereological issue at stake: is the intentional object a part of the experience?}

\subsection{The sketch of the problem in Brentano's Psychologie}

The first problem I will consider pertains to the relationship between the act and the intentional object. Again, this issue originates in Brentano. In his Psychologie, he defined intentionality as the "mental inexistence" or "immanent" existence of an object in the psychic phenomena (Brentano 1973, p. 124). Yet his words are quite puzzling. On the one hand, the term "inexistence" aims at emphasizing that the intentional object must not be confused with the real object that exists in nature. It is in particular the case when the intentional object is fictional or impossible (Brentano 1995, p. 24). On the other hand, the intentional object must be, in one way or another, related to the act, so that the latter can be directed towards it. The most straightforward relationship at stake is the one of parthood: Brentano thus for instance asserts that this immanent object is contained (enthalten) (Brentano 1973, p. 125; $5^{\text {th }}$ LI, p. 367 [II, p. 95]) or inherent (einwohnendes) (Brentano 1982, p. 22) in the act.

These two theses are not easily reconciled. How is this inexistent object supposed to be a part of an existent one, namely the act, which is real? This would imply that a real object can have parts that are not real - which seems absurd. On the other hand, if we are to deny the inclusion of the intentional object within the act, what is then the kind of relation between the two?

These issues were at the core of the much interesting debates between Stumpf, Marty, Twardowski, Brentano, and Husserl (Rollinger 1999). Given the purpose of this paper, I will restrain my analysis to the Husserlian critique of Brentano and Twardowski.

\subsection{Husserl against Twardowski and the image theory}

Husserl seems to offer a direct and clear-cut answer to the issue, by asserting that the intentional object cannot be considered as a part of the act at all: 
We do not experience the object and beside the intentional experience directed upon it, there are not even two things present in the sense of a part and a whole which contains it: only one thing is present, the intentional experience $\left(5^{\text {th }} \mathrm{LI}\right.$, p. 372 [II, p. 98]).

This position can be traced back to the 1894 essay entitled "Intentional objects" (Husserl 1994b, pp. 345-387), directed against Twardowski's position. ${ }^{1}$ The latter emphasized, in his Zur Lehre vom Inhalt und Gegenstand der Vorstellungen (Twardowski 1977), that the immanent object of the presentation was "the opposite of a genuine object": "The presented object is then no longer an object, but a content of a presentation" ( $\$ 4$, translated in Twardowski 1977, pp. 13-14). As a result, for Twardowski, while the genuine object does not belong to the act, the immanent object is rigorously a part of its content.

Husserl addresses three main criticisms against such a conception.

First, it is useless. Husserl emphasizes that the introduction of such an immanent object, or "image", within the act does not explain what "enables us to go beyond the image which alone is present in consciousness, and to refer to the latter as an image to a certain extraconscious object" $\left(5^{\text {th }} L I\right.$, p. 422 [II, p. 125]).

Second, it is impossible. One of its main goal is to deal with 'objectless presentations', such as the presentation of the round square. It is quite straightforward that, even though there is no such thing as a round square, its presentation exists - to deny the existence of the round square requires that the latter is put before the mind. Twardowski's solution precisely consists in asserting that it is the genuine round square that is denied when I have before the mind the round square as immanent object, as a content, which "exists in the truest sense of the word" (Twardowski 1977, p. 22). But it is evident that, in this case, "if a round square is immanent in the representation $[\ldots]$, then there would be a round square in the representation" (Husserl 1994b, p. 352) which is impossible.

Third, when applied to ideal objects such as concepts, numbers, ${ }^{2}$ and logical laws, Twardowski's 'immanentism' leads to psychologism.

As Husserl puts it in the Prolegomena:

\footnotetext{
${ }^{1}$ Husserl also wrote a draft review (in 1896) of Twardowski's book (published in Husserl 1979, pp. 303-356). Cf. (Cavallin 1997, p. 29) for historical details on these texts. ${ }^{2}$ See in particular Prolegomena, p. 171 [I, p. 110]: numbers, as ideal entities, are in no way "part or side of a mental experience".
} 
the concept can in no sense be regarded as a real (reell $)^{1}$ part of this psychological content, as something here and now, which comes and goes with the act (Prolegomena, p. 132 [I, p. 87]).

The concept is thus only "meant" (id.) in the act, but not really present in it as a reeller part (Introduction to the second volume p. 16 [I, p. 174]). Such exclusion is fundamental to avoid the confusion between the act and its object, between the real and the ideal, and thus to escape the skepticism that is the necessary consequence of psychologism.

\subsection{The reintegration of the intentional content and the concept of noema}

Husserl's position seems thus quite clear-cut: the intentional object cannot be understood as a part of the experience: the latter is real, a part of a real entity is itself real - which is not the case for ideal or contradictory objects. However, this apparently settled position must be nuanced, because it cannot suffice to a comprehensive understanding of the issue at stake. It could lead to the idea that, since the intentional object does not belong to the act, the only parts of experiences are their real (reellen) parts ( $5^{\text {th }} L I$, p. 397 [II, p. 112]), corresponding to everything that is descriptively 'present' in a given experience, minus its 'objective sense'.

Husserl gives the example of a sound: "purely descriptive psychological analysis of an articulated sound-pattern finds only sounds and abstract parts or unifying forms of sounds" (id.), but does not find, by contrast, anything like the meaning that ensouls these sounds into a name. In other terms, the reellen contents of an act are the mere sensations. ${ }^{2}$

Yet it is plain that the sensations do not exhaust the act: a mere sensational experience would be non-intentional, as is the case of a pain. Hence, in

\footnotetext{
${ }^{1}$ This term must not be confused with the word real. 'Real' designates the empirical existence of a thing, as opposed to the ideal 'being' of species, numbers, etc. 'Reell', by contrast, is opposed to 'intentional', and refers to what is immanent to consciousness.

${ }^{2}$ Husserl appeals to a variety of terms to designate these sensations: "sensory contents" (Empfindungsinhalten), "presentative contents" (darstellende Inhalte) (5 $5^{\text {th }} L I$, p. 392 [II, p. 109]), "representative contents" (repräsentierende Inhalte) (6 $6^{\text {th }} L I$, p. 90 [II, p. 242]), "representants" (Repräsentanten) ( $6^{\text {th }} L I$, p. 91 [II, p. 243, translation modified]), or "primary contents" (primäre Inhalte) ( $6^{\text {th }} L I$, p. 180 [II, p. 304]).
} 
addition to the real content of the act, one must add its "intentional content"1 ( $5^{\text {th }}$ LI, p. 397 [II, p. 113]). Here new difficulties arise, because the status of this latter content is ambiguous. If we think of it as being a part of the whole, are we not led, again, to the previous 'immanentist' conception of Twardowski'? And if it is no such part, how can it be depicted as a content in the act?

As I understand it, it is only between 1901 and 1913 (Lavigne 2005), with the invention of the concepts of noesis, noema (Husserl 1950, §88), and phenomenological reduction, that Husserl is able to deal with this question.

In the natural attitude, the act is just an entity within the world, belonging to a certain peculiar realm, the sphere of consciousness, understood here as a "natural reality" (Real) which enters into real relationships with other natural realities. Yet when "we deal with the lived experience as an object like any other", the only parts that can be unveiled in it are the real (reell) ones (Husserl 1950, p. 218). Of course, as Husserl notes, the intentional 'dimension' of the act already belongs to it in the natural attitude (Husserl 1950, p. 222). Yet the mereological status of this 'dimension' is, in this naïve attitude, in need of clarification. What can it mean for the intentional content to belong to the act without being a real part of it, just like the sensations? Where, so to speak, should we 'localize' the intentional contents, if not within the act? If the natural attitude is maintained, its 'natural' consequence is thus Twardowski's image theory. This is acknowledged by Husserl himself in the $\S 90$ of the Ideen, where he deals again with the issue of "immanent objects": the only way to avoid such "errors" is to parenthesize the "'actual' (wirkliche) object", that is, to operate the phenomenological reduction (Husserl 1950, p. 225).

Once this is accomplished, the situation is greatly clarified. The ontological nature of the act is now its reduced being. Everything that can be distinguished in this reduced experience truly belongs to the act. Its intentional

\footnotetext{
${ }^{1}$ Some of the most interesting additions of the second edition concerns the fact that phenomenology is, in 1913, no longer restrained to the study of the reell content of the act, and extends to its intentional content. See the crucial note on this subject $\left(5^{\text {th }} L I\right.$, p. 397 , n. 1 [II, p. 354, n. 24]). See also the additions of the term "reell" ( $5^{\text {th }} L I$, p. 371 [II, p. 98]; $5^{\text {th }} L I$, p. 412 [II, p. 120]), and a passage added to the "Appendix" to the $L I$ : "Phenomenology is accordingly the theory of experiences in general, inclusive of all data (Gegebenheiten), whether real (reellen) or intentional, given in experiences, and evidently discoverable in them" (Appendix, p. 236 [II, p. 343]).

${ }^{2}$ Such risk is increased by some inconsistencies in Husserl's terminology. In the $\$ 16$, he clearly distinguishes the reelle and the intentional content. Yet in the $\S 45\left(5^{\text {th }} \mathrm{LI}\right.$, p. 506 [II, p. 175]), he includes both the intentional essence and the sensory content within the reelle content, here understood by contrast with the logical, ideal meaning.
} 
content (the noema ${ }^{1}$ (Lavigne 2005, p. 51, n. 51)), from this new perspective, is no longer something that goes beyond its immanent constituents, since, precisely, there is nothing beyond the act, beyond the self-given experience. Hence the intentional content is reintegrated within the "immanent" (Husserl 1950 , p. 219) components of the act, is a genuine "eidetic moment" (Husserl 1950, p. 221) of the latter. The reduction thus does not lead to a 'narrowing' of the experience; on the contrary, it 'expands' it beyond the reellen borders imposed by the natural-psychological attitude, it increases the sphere of experiential immanence (Lavigne 2005, p. 548).

One may sum up the Husserlian position as follows:

\section{Proposition 4:}

The intentional object is not a part of the reelle content of an act.

\section{Proposition 5:}

If, by 'intentional object', we understand, adopting the transcendental attitude, the noema, then the intentional object is a part of the (reduced) act.

Husserl's position regarding the question whether the intentional object is a part of the act has far-reaching implications. It may even be said that his conception of transcendental idealism is in fact the full development of his answer to this issue. It consists indeed on the one hand in rejecting the 'subjective idealism' (Husserl 1950, p. 134) that is inescapably involved in the 'image theory', since the subject would then only deal with subjective images or signs, and could never attain anything real. Yet on the other hand, it also consists in reintegrating the noema inside the reduced experience, so that the object is now nothing more than what is constituted in the experience itself.

\section{The second mereological issue: are all acts mere presentations or founded on mere presentations?}

\subsection{The sensational and the intentional parts of the act}

Let's now turn to the second mereological issue at stake in this $5^{\text {th }} L I$, which is in fact intimately connected to the first one.

If we stick to the terminology used in the $L I$, one must distinguish between the sensational and the intentional parts (or contents) of the act $\left(5^{\text {th }} \mathrm{LI}\right.$,

\footnotetext{
${ }^{1}$ It may be noted that the word itself appeared quite late, namely in 1912, during the redaction of the Ideen (Lavigne 2005, p. 600).
} 
$\S 16)$. The latter, also labeled "act-character", is precisely the element of the act that accounts for its 'aiming' at its intentional object. ${ }^{1}$ These two parts of the intentional content are not symmetrical. Indeed, as we saw, for Husserl (as opposed to Brentano), non-intentional experiences exist:

That not all experiences are intentional is proved by sensations and sensational complexes. Any piece of a sensed visual field, full as it is of visual contents, is an experience containing many part-contents, which are neither referred to, nor intentionally objective, in the whole ( $5^{\text {th }} L I$, p. 369 [II, p. 97]).

As a result, these experiences do not have an intentional part: they solely consist of a sensational part. Hence this latter is a 'self-sufficient' (see p. 8) part of the act, since it does not require any supplementary content to exist. On the contrary the act-character is necessarily dependent on the sensations: there can be no 'interpretation' without something interpreted, namely, the underlying sensations that appear as being a tree, a dog, etc.

This thesis, which could seem quite straightforward, has actually crucial implications regarding Husserl's theory of intuition. It is indeed the presentative contents which account for the intuitive character of acts (in perceptive or imaginative experiences) ( $6^{\text {th }} L I$, pp. $78-79$ [II, p. 235]). The very same intention, directed to the very same object, can be full or empty. Differences of fulness thus do not affect the intentional essence ${ }^{2}$ of the act $\left(5^{\text {th }} L I\right.$, p. 420 [II, p. 124]). It may accordingly be thought that intuitive acts are those whose presentative contents are the richest, and "signitive" or symbolic acts $\left(6^{\text {th }} L I\right.$, p. 88 [II, p. 241]) those which are devoid of any such contents. Yet it is precisely what is impossible due to the founded character of the intentional part of the act. As Husserl puts it:

A purely signitive act would be a mere complex of quality and matter, if indeed it could exist by itself at all, i.e. by a concrete experiential unity 'on its own'. This it cannot be: we always find it clinging to some intuitive basis (id.).

What then distinguishes signitive and intuitive acts is the function of the presentative contents: in the latter, the object itself (or its analogon in the case of imagination) is presented through the presentative contents; in the former,

\footnotetext{
${ }^{1}$ As recalled, in the $L I$, Husserl does not distinguish between noesis and noema. Hence the "act-character" is both the operation, Leistung, that constitutes the intentional object, as well as the objective sense thus constituted.

${ }^{2}$ The intentional essence of an act is constituted by the union of its matter and quality. The precise definition of these terms will be given in a few lines.
} 
these contents only play the role of a sign, they "have "nothing at all to do" (id.) with the intended object. It is thus not the mere presence or absence of presentative contents that account for intuitiveness, but rather their role vis-àvis the intention at stake.

We may sum up this one-sided foundation between the sensational and the intentional part as follows:

\section{Proposition 6:}

An 'intentional content' cannot exist without being supplemented by a 'sensational content', and is thus an abstract ('non self-sufficient') part of the act. By contrast, a 'sensational content' can exist on its own and is thus a concrete ('self-sufficient') part of the act. The foundation of the intentional content upon the sensational content is thus one-sided, and not reciprocal.

\subsection{Intentional matter and intentional quality}

These two parts are themselves mereologically structured. In the $5^{\text {th }} L I$, Husserl analyzes in particular the components of the intentional part that he labels "matter" (Materie) and "quality" (Qualität). This couple of concepts originates again in Brentano's teachings, as Husserl acknowledges (Husserl 1979, p. 187), but is deeply transformed by the latter. Brentano applies these notions to the domain of judgments. Matter (Materie) is the "judged (Beurteilte) as such", for instance, what the name names. By contrast, the quality (or form) is the "mode" (Weise) of the judgment, which accounts for its being a judgment (Brentano 1956, p. 103). Let's recall that for Brentano, judgments are not mere combinations of presentations (Brentano 1956, p. 98, 1971, p. 44), but are characterized by a specific type of reference to their object, namely their acknowledging (affirmative judgments) or rejecting (negative judgments) (Brentano 1956, p. 104, 1971, p. 34). ${ }^{1}$

Husserl, on the one hand, maintains the most prominent feature of Brentano's concepts of Materie and Qualität, namely, the distinction between the what, the Was, and the how, the Wie, of an act, but, on the other hand, he expands these concepts beyond their original logical domain, and apply them to the entire realm of acts. In this perspective, two judgments share the same quality: they both refer to their objects as judgments do. In a parallel fashion, wishes all refer to their objects as wishes do, etc.

${ }^{1}$ On Brentano's conception of judgment, see (Brandl and Textor 2018). On its Husserlian reception, see (Husserl 1979, p. 187; Rollinger 2004, p. 200). 
Yet these different ways of referring to an object can share 'the same content'. As Husserl puts it,

a man who frames the presentation 'There are intelligent beings on Mars' frames the same presentation as the man who asserts 'There are intelligent beings on Mars', and the same as the man who asks 'Are their intelligent beings on Mars?' etc. ( $5^{\text {th }} L I$, p. 412 [II, p. 120]).

Matter is thus defined as this 'same' which is presented, asserted, wished, etc., in these different acts. Husserl emphasizes that this material moment also encompasses the precise 'path' used to refer to the object. For instance, the representations ' $a+b$ ' and ' $b+a$ ' do not share the same matter.

Husserl states that both matter and quality are abstract parts that cannot exist in isolation from each another ( $5^{\text {th }} L I$, p. 416, p. 456 [II, p. 122, p. 145]), exactly like color and extension ( $5^{\text {th }} L I$, p. 435 [II, p. 133]). Even a 'mere presentation', in which the object is presented without any belief attached to it, has a certain quality, which corresponds precisely to the 'manner' according to which such 'mere presentation' refers to its object.

Let's now sum up, using a graph, the mereological composition of intentional experiences. We represent the parthood relation by a descendant segment. In addition, the names of concrete parts ('self-sufficient') will be filled in red, and those of abstract parts ('non self-sufficient') in blue. 
Figure 1: The mereological structure of intentional experiences

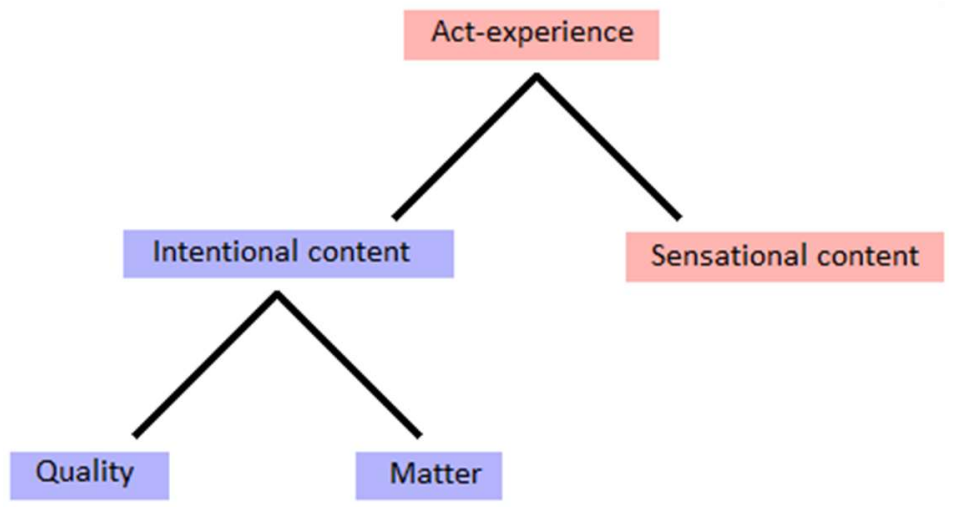

\subsection{Brentano's thesis and Husserl's objections}

Husserl is now able to confront himself with a famous Brentanian thesis, according to which acts are presentations (Vorstellungen) or are based on presentations.

It is first needed to clarify the meaning of the concept of Vorstellung here at stake. Brentano distinguishes it, as we have seen, from judgments: only in the latter is the object affirmed or denied. As a result, in a Vorstellung, the object is merely presented (hence the term of bloße Vorstellung, mere presentation, used by Husserl). ${ }^{1}$ Such is in particular the case of imagination: I have the lion before my mind, but I do not acknowledge its existence - nor do I deny it. For Brentano, judgments, as well as affective acts, have presentations at their base: for something to be acknowledged or loved, it is first needed that it is presented, that it appears before one's mind.

Such a statement seems to be plain: affirmation and negation, love and hate, are nothing but supplementary layers that must be added to a pregiven object. Yet an important problem would then emerge. According to Husserl, what constitutes the reference to an object in an act is its matter. Hence, matter plays exactly the same role as the underlying 'mere presentations' of an act: it

\footnotetext{
${ }^{1}$ This concept of presentation can in fact be traced back to the Stoic distinction between the 'impression' (phantasia) and the 'assent' that leads to a belief, and, later, to Descartes' classification (quoted by Brentano 1969, p. 17) of pensées in idées, jugements, and affections (Third Meditation).
} 
constitutes its 'objective reference', the Was which is imagined in an imaginative act, judged in a judgment, etc. But 'mere presentations' are concrete acts, they can exist on their own! The initial thesis would therefore imply that matter is an independent part of the whole, which is not the case.

To understand this problem, we can appeal to a comparison between two acts. Consider first a wish. I necessarily wish something. The object of my wish must be given in a certain act, say, an imagination. The mereology of the wish is straightforward: this imaginative act is independent from the wish, as it can still be there while my wish has disappeared. In this first case, it is clear that the wish is added to an underlying concrete 'mere presentation'.

The case of perception is fundamentally different. Husserl appeals to his famous example of the waxwork woman ( $5^{\text {th }} L I$, pp. 442-44 [II, pp. 137-139]). I first perceive a woman, I believe that the woman exists. Yet, when I acknowledge the trick, I stop perceiving a woman, and, instead, I see a wax figure representing a woman, thus a 'mere presentation'. Husserl emphasizes that the two experiences are conflicting: "our observation wanders from one to another of the apparent objects each barring the object from existence" $\left(5^{\text {th }} L I\right.$, p. 443 [II, p. 138]). Hence the two attitudes according to which I 'refer' to the presented woman are incompatible. If the 'mere presentation' was part of the original perception, I would at the same time adopt two contradictory attitudes: "A percept cannot also fictitiously construct what it perceives" $\left(5^{\text {th }} \mathrm{LI}, \mathrm{p} .444\right.$ [II, p. 139]). Both have a moment in common, that is their matter, since it is indeed the same woman that is presented in both cases; but the two acts are distinct regarding their quality, which accounts for the difference of attitudes.

The objections addressed by Husserl to his teacher Brentano are thus mereological in their essence: a mere presentation is not part of a perception: they only overlap through their matter. ${ }^{1}$

Let's sum up Brentano's and Husserl's positions with figures illustrating the case of perception:

${ }^{1}$ The same reasoning applies to state of affairs ( $5^{\text {th }} L I$, p. 450 [II, p. 142]).

19

Bull. anal. phén. XVII 4 (2021)

https://popups.uliege.be/1782-2041/ @ 2021 ULiège BAP 
Figure 2: Brentano's thesis (interpreted within Husserl's conceptual apparatus)

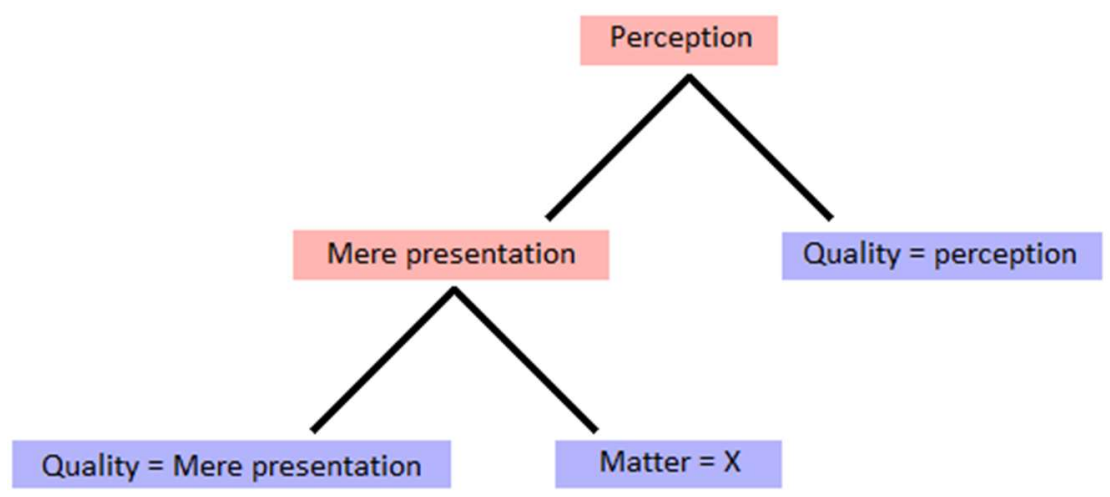

Figure 3: Husserl's solution

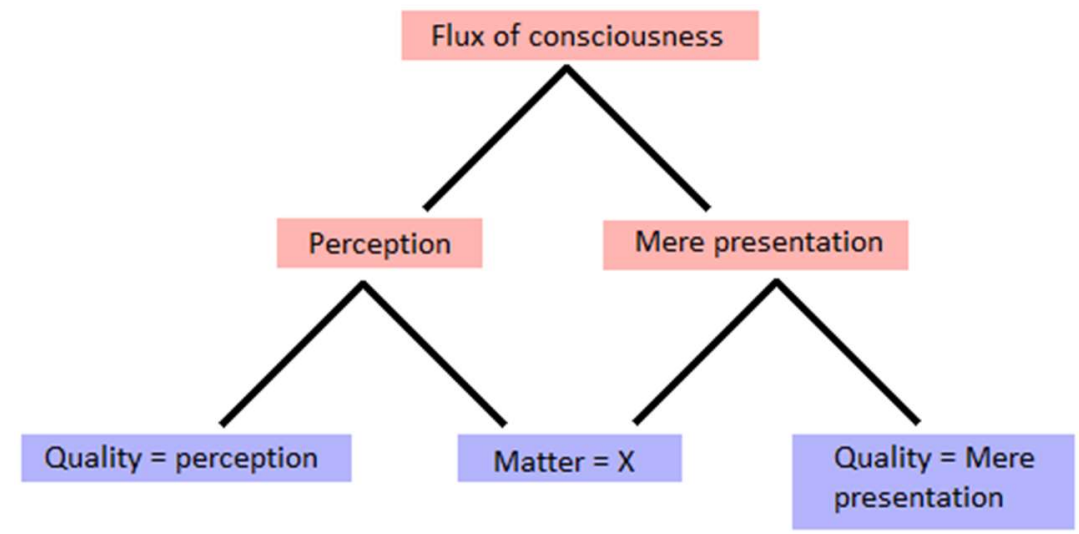

\subsection{Husserl's reinterpretation of Brentano's thesis}

In chapters 3 and 4 of this $5^{\text {th }} L I$, Husserl forges a new notion of presentation in order to re-establish, under a new form, the Brentanian law. The fundamental concept developed by Husserl is the one of objectifying acts (Erhard and Mayer 2008; Melle 1990). Husserl's aim is to show that "each intentional experience is either an objectifying act or has its basis in such an act" $\left(5^{\text {th }} L I\right.$, p. 493 [II, p. 167]). 
This concept is introduced through two distinctions ( $5^{\text {th }} L I$, p. 481 [II, p. 160]). First, the difference between the positing or non-positing character of an act. An experience is 'positing' if it involves a belief. Such is for instance the case in a perception. Non-positing experiences are precisely 'mere presentations'. Second, the distinction between nominal and propositional characters of acts. This distinction basically corresponds to the difference between a name and a judgment. A nominal act is, as Husserl puts it, "single-rayed". The object is referred to as simple. By contrast, a propositional act is "many-rayed" $\left(5^{\text {th }}\right.$ $L I$, p. 481 [II, p. 160]).

This new definition, which leads to an authentic species of acts, as Husserl emphasizes ( $5^{\text {th }} L I$, p. 485 [II, p. 162]), is clearly an extension of the previous definition of Vorstellung. The class of objectifying acts, in addition to neutral experiences, also includes their positing counterparts. By contrast, are excluded from this class all acts in which an object is not merely presented (with or without assent to its existence) but is also wished, loved, etc.

Given this definition, Husserl is able, quite easily, to prove his theorem. Indeed, these acts, and only them, can provide a matter to any act. Hence:

Objectifying acts have the peculiar function of first providing other acts with presented objects, to which they may then refer in their novel way $\left(5^{\text {th }} L I\right.$, p. 494, [II, p. 167, trans. modified]).

Husserl's point is therefore that any attitude that I adopt towards such-andsuch object requires that this object is presented to me. Hence, the acts in which I adopt these attitudes must be founded on objectifying ones. ${ }^{1}$

\section{Proposition 7:}

All acts are objectifying acts or founded on objectifying acts.

Hence the following representation:

\footnotetext{
${ }^{1}$ This thesis is at the core of Husserl's intellectualism: the objects of the world can be presented independently from our affective attitudes, our desire, hate, hope, etc. In non-Husserlian terms, there is a purely objective access to the world. This intellectualism is maintained in the Ideen despite the disappearance of the concept of objectifying acts (see $§ 95)$.
} 
Figure 4: An act of joy

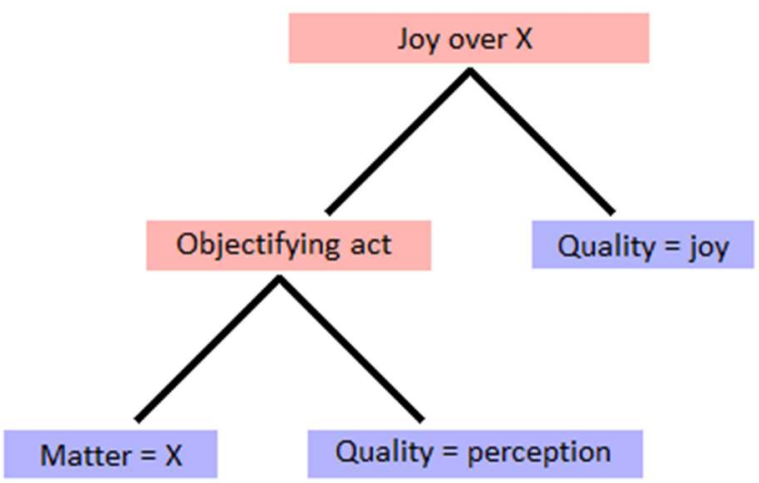

We can also represent the same act of joy with the following figure:

\section{Figure 5: Another representation of an act of joy}

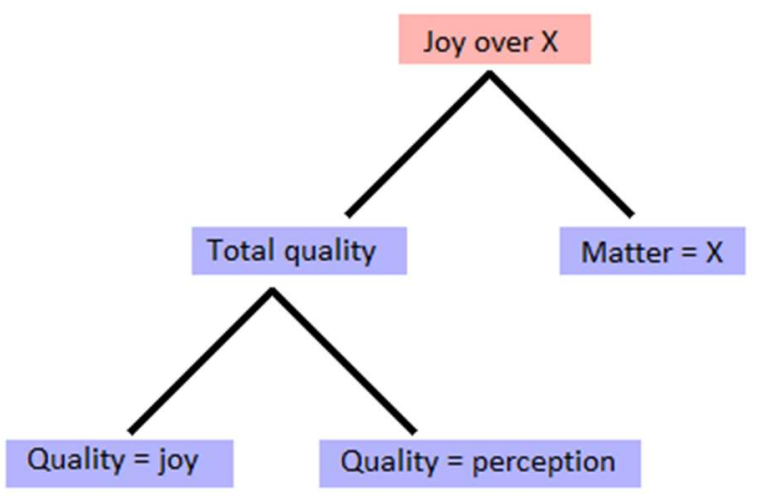

This figure explains why Husserl states that the "complex total quality divides into several qualities, each having individually the same common matter" (5 $5^{\text {th }} L I$, p. 495 [II, p. 168]). In the latter representation, the stress is put on the mereology of the quality of an act.

We are thus led to the following proposition:

Proposition 8:

The total quality of any act has a part which is a quality of the objectifying kind. 
But we can even go further. Let's consider more complex acts. Sometimes we may not be able to anticipate our feelings towards a scheduled event. A woman I love is getting married with another person. The wedding is planned for tomorrow, and I will attend: will I be happy for her, or will I be overwhelmed by jealousy? From a moral point of view, I hope I will be happy. In this kind of situations, a complex act of "a hope for joy" thus occurs. It is possible to account for this kind of acts in an Husserlian framework. Yet one must be very cautious. For instance, the following figure, which aims at representing this act of a hope for joy, is in accordance with Propositions 8 and 9:

\section{Figure 6: An impossible representation of a hope for joy}

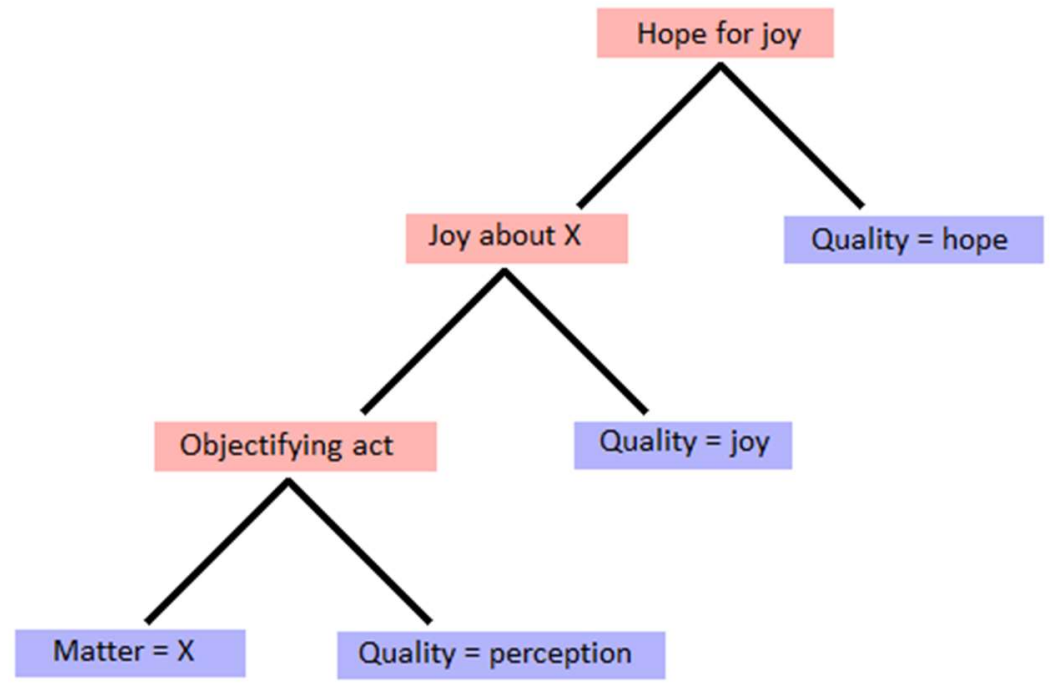

Yet this act is a priori impossible. For, as Husserl puts it,

qualities of other kinds are accordingly always founded on objectifying qualities; they can never be immediately associated with matter in their own right (5 $5^{\text {th }} L I$, p. 495 [II, p. 168]).

The problem in the previous figure is thus the following: the matter of the hope is 'the joy about $X$ '. This joy is the object of the whole act, and 'hope' its quality. Yet, in the figure, this matter is immediately associated with the quality 'hope'. The fact that the matter 'joy about $X$ ' includes an objectifying act is irrelevant. Husserl's law prevents this situation: an act-quality that is not of the objectifying kind 
has its primary foundation in another act-quality [of the objectifying kind] and is only mediately founded on 'matter' ( $5^{\text {th }} L I$, p. 498 [II, pp. 169-170]).

This law reveals, once again, how important the $3^{\text {rd }} L I$ is in order to shed light on Husserl's phenomenology. Here, the concepts of mediate and immediate parts, and, more precisely, the concepts of absolutely mediate and immediate parts, play a crucial role. A mediate part is defined $\left(3^{r d} L I, \S \S 18-19\right)$ as a part of a part. Husserl emphasizes that, most of the time, such mediacy is quite arbitrary: the parts of a surface can be both considered as immediate and as mediate parts of the whole. Yet there are essentially mediate parts as well: the intensity of a note is a part of the whole melody, but is essentially a mediate one. The same holds for the relation between objectifying and non-objectifying qualities, as it involves a necessary mediation: the matter cannot be attained except by reaching first the objectifying act. Hence, the matter of a non-objectifying act is an absolutely mediate part of the whole. The joy about $X$ must be itself presented as the matter of an objectifying act, through an objectifying quality, for instance an 'internal perception' $(I P)$. By contrast, the objectifying act must be itself an absolutely immediate part of the whole act. A correct representation of a hope of a joy would accordingly be: 
Figure 7: A correct representation of a hope for joy ${ }^{1}$

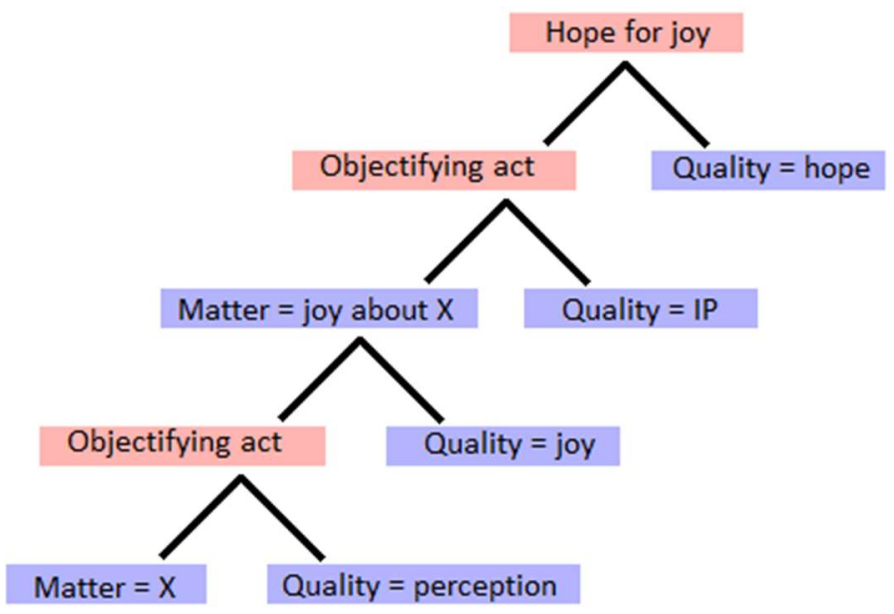

This explanation leads to the following, more complete a priori laws:

Proposition 9:

Every non-objectifying act has an absolutely immediate part which is an objectifying act.

Proposition 10:

The matter of a non-objectifying act is an absolutely mediate part of it, being a part of its underlying objectifying act.

The figure representing this universal law is the following:

\footnotetext{
${ }^{1}$ Here, I assume that the second objectifying act, which supports the desire, is a concrete act. Hence $a$ part of an abstract part of a whole can be an independent part of the whole. From a formal-ontological point of view, it is not as strange as it sounds: the independent part can exist on its own, but the reunion of the latter and a dependent part cannot, and is thus dependent.
} 
Figure 8: The general mereological structure of non-objectifying acts ${ }^{1}$

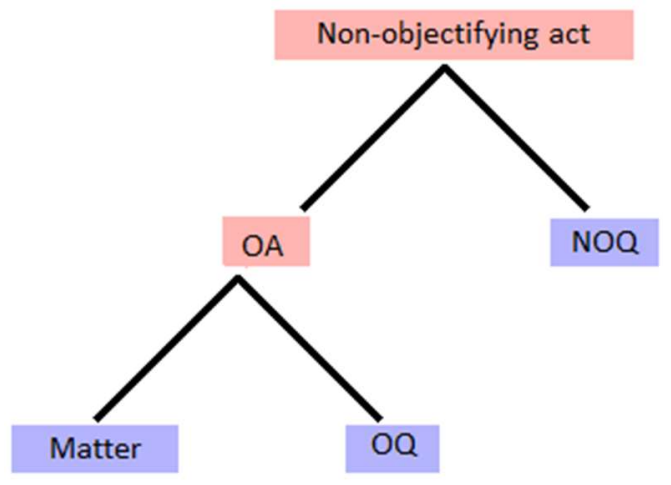

Such is the mereological meaning of Husserl's reinterpretation of Brentano's law.

\section{Conclusion}

It is now time to conclude this paper, by coming back to the two issues that we exposed in the introduction.

First, from the point of view of the Husserlian scholarship, we have emphasized the extent to which the concepts involved in the $3^{r d} L I$ are used in Husserl's phenomenology. It is not only the case of the famous notions of foundation, dependence and independence, abstractness and concreteness. We indeed saw that Husserl actually appeals to the precise definition of unity and whole, to the distinction between immediate and mediate parts, as well as to the difference between relative and absolute dependence. The whole conceptual apparatus built in the $3^{\text {rd }} \mathrm{LI}$ is thus at stake.

Showing the links between the $3^{\text {rd }}$ and the $5^{\text {th }}$ Investigations is decisive in order to apprehend Husserl's global projects. In particular, it emphasizes the systematic character of the Logical Investigations, which is not straightforward (D. W. Smith 2003, p. 21). Husserl himself has emphasized that the six Investigations are "mutually interdependent" (Husserl 1984b, p. 779), that they are a "systematically bound chain of investigations" (Foreword to the second edition, p. XI [I, p. 5]), and that, in particular, the $3^{\text {rd }} L I$ is "an essential presupposition for the full understanding of the Investigations which follow" (ibid.,

${ }^{1} \mathrm{OA}=$ Objectifying Act; (N)OQ = (Non-)Objectifying Quality. 
p. XV [I, p. 7]). Our paper has contributed to illustrate these claims. It is worth noting that the dependence between the $3^{\text {rd }}$ and the $5^{\text {th }} L I$ is reciprocal, and not one-sided: the very notion of analytic truth, that is at the core of formal ontology to which mereology belongs, requires an elucidation of the notion of truth, that rests eventually on a phenomenological analysis of intentional experiences.

Second, we have shown how Husserl's mereology provides concrete and useful tools so as to 'rationalize' the domain of consciousness. Husserl thus manages to reconcile the two sides of the dilemma tackled in the introduction. On the one hand, the Husserlian notion of formal ontology allows him to consider everything as 'objects' and to study the laws that apply to objects as such. This holds for experiences, too: the elements of consciousness are not some special, mysterious, entities, they obey, like anything else, the laws of formal ontology ( $2^{\text {nd }} L I$, p. 218 [I, p. 309]). As a result, they can be individualized, named, and thus mutually distinguished; they may also be gathered into ideal species, which in turn serve as the founding stones for the establishment of laws. Yet the phenomenological laws are not formal: they are material-synthetic, that is, they are adapted to their peculiar domain. It is up to the tools of the $3^{r d} L I$ to provide the basic structures thanks to which we can translate the reflections upon our mental life into fixed, rigorous and general propositions.

\section{Acknowledgments}

I would like to thank Achille Varzi for having aroused my interest in contemporary mereology, as well as Natalie Depraz, Thomas Fuchs and Mathilde Salvador for their indispensable support and help.

\section{References}

Benoist, J. (2001). Intentionalité et langage dans les «Recherches logiques» de Husserl. Paris: Presses universitaires de France.

Bergson, H. (2001). Time and Free Will: An essay on the Immediate Data of Consciousness. (F. L. Pogson, Trans.). Dover.

Brandl, J. L., \& Textor, M. (2018). Brentano's Theory of Judgement. The Stanford Encyclopedia of Philosophy. https://plato.stanford.edu/archives/win2018/entries/brentano-judgement/. Accessed 20 August 2020

Brentano, F. (1956). Die Lehre vom richtigen Urteil. (F. Mayer-Hillebrand, Ed.). Hamburg: Meiner. 
Brentano, F. (1969). Vom Ursprung sittlicher Erkenntnis. (O. Kraus, Ed.). Hamburg: Felix Meiner Verlag.

Brentano, F. (1971). Psychologie vom empirischen Standpunkt. (O. Kraus, Ed.) (Vol. II). Hamburg: Meiner.

Brentano, F. (1973). Psychologie vom empirischen Standpunkt. (O. Kraus, Ed.) (Vol. I). Hamburg: Meiner.

Brentano, F. (1974). Psychologie vom empirischen Standpunkt. (O. Kraus, Ed.) (Vol. III). Hamburg: Meiner.

Brentano, F. (1982). Deskriptive Psychologie. Hamburg: Felix Meiner Verlag.

Brentano, F. (1995). Descriptive Psychology. Routledge.

Brentano, F. (2013). Über die Zukunft der Philosophie nebst den Vorträgen: Über die Gründe der Entmutigung auf philosophischem Gebiet: Über Schellings System sowie den 25 Habilitationsthesen. (O. Kraus, Ed.). Felix Meiner Verlag.

Casari, E. (2007). On the Relationship between Parts and Wholes in Husserl's Phenomenology. In L. Boi, P. Kerszberg \& F. Patras (Eds.), Rediscovering Phenomenology (pp. 67-102). Springer.

Cavallin, J. (1997). Content and Object: Husserl, Twardowski and Psychologism. Springer Science \& Business Media.

Cobb-Stevens, R. (2003). Husserl's Fifth Logical Investigation. In D. O. Dahlstrom (Ed.), Husserl's Logical Investigations (pp. 95-107). Springer.

Erhard, C., \& Mayer, V. (2008). Die Bedeutung objektivierender Akte. In V. Mayer (Ed.), Logische Untersuchungen (pp. 159-188). Berlin: Akademie Verlag.

Fisette, D. (2011). Brentano et Husserl sur la perception sensible. Bulletin d'Analyse Phénoménologique, VII(1), 37-72.

Gilson, L. (1966). Science et philosophie selon F. Brentano. Revue internationale de Philosophie, 20 (78 (4)), 416-433.

Godani, P. (2010). Corrélation et immanence chez Bergson et Husserl. Philosophie, $107(4), 46-66$.

Henry, M. (2011). L'essence de la manifestation (4th ed.). Presses universitaires de France.

Henry, M. (2012). Barbarism. Continuum.

Hering, J. (1939). La phénoménologie d'Edmund Husserl il ya trente ans. Souvenirs et réflexions d'un étudiant de 1909. Revue internationale de philosophie, 1(2), 366-373.

Huemer, W. (2018). Brentano's Conception of Philosophy as Rigorous Science. Brentano Studien, 16, 53-71.

Husserl, E. (1913a). Logische Untersuchungen (2nd ed., Erster Band: Prolegomena zur reinen Logik). Halle: Verlag von Max Niemeyer.

Husserl, E. (1913b). Logische Untersuchungen (2nd ed., Zweiter Band: Untersuchungen zur Phänomenologie und Theorie der Erkenntnis, I. Theil). Halle: Verlag von Max Niemeyer.

Husserl, E. (1921). Logische Untersuchungen (2nd ed., Zweiter Band: Elemente einer Phänomenologischen Aufklärung der Erkenntnis, II. Theil). Halle: Verlag von Max Niemeyer. 
Husserl, E. (1950). Ideen zu einer reinen Phänomenologie und phänomenologischen Philosophie. Erstes Buch: allgemeine Einfürung in die reine Phänomenologie (Hua 3). (W. Biemel, Ed.). Den Haag: Martinus Nijhoff.

Husserl, E. (1977). Phenomenological Psychology. Lectures, Summer Semester, 1925. (J. Scanlon, Trans). The Hague: Martinus Nijhoff.

Husserl, E. (1979). Aufsätze und Rezensionen (1890-1910) (Hua 22). The Hague: Martinus Nijhoff.

Husserl, E. (1982). Ideas pertaining to a Pure Phenomenology and to a Phenomenological Philosophy. (F. Kersten, Trans.). The Hague: Martinus Nijhoff.

Husserl, E. (1984). Logische Untersuchungen. Zweiter Band. Untersuchungen zur Phänomenologie und Theorie der Erkenntnis (Hua 19) (Vols. 1-2). Edited by Ursula Panzer. The Hague: Martinus Nijhoff.

Husserl, E. (1991). On the Phenomenology of the Consciousness of Internal Time (1893-1917). (J. B. Brough, Trans.). Kluwer Academic Publisher.

Husserl, E. (1994a). Briefwechsel (Hua Dokumente III). (K. Schuhmann, Ed.) (Vols. 1-10). Dordrecht: Kluwer Academic Publishers.

Husserl, E. (1994b). Early Writings in the Philosophy of Logic and Mathematics. (D. Willard, Trans.). Springer.

Husserl, E. (2001). Logical Investigations (Vols. 1-2). London ; New York: Routledge. Translated by J. N. Findlay.

Ingarden, R. (1922). Intuition und Intellekt bei Henri Bergson. Jahrbuch für Philosophie und phänomenologische Forschung, V, 285-461.

Ingarden, R. (1969). Le concept de philosophie chez Franz Brentano. Archives de philosophie, 32(3), 458-475.

Ingarden, R., \& Husserl, E. (1968). Briefe an Roman Ingarden-Mit Erläuterungen und Erinnerungen an Husserl. Den Haag: Martinus Nijhoff.

Inwagen, P. van. (1987). When Are Objects Parts? Philosophical Perspectives, 1, 21 47.

Kraus, O. (1919). Franz Brentano: zur Kenntnis seines Lebens und seiner Lehre. Beck.

Lavigne, J.-F. (2005). Husserl et la naissance de la phénoménologie (1900-1913). Des «Recherches logiques» aux «Ideen»: la genèse de l'idéalisme transcendantal phénoménologique. Presses universitaires de France.

Leclerq, B., \& Galetic, S. (2012). James et Husserl : Perception des formes et polarisation des flux de conscience. Revue internationale de philosophie, $n^{\circ} 260(2), 229$ 250.

Lorca, D. (1999). Husserl's Theory of Consciousness in the Fifth Logical Investigation. Journal of the British Society for Phenomenology, 30(2), 151-165.

Marbach, E. (1974). Das Problem des Ich in der Phänomenologie Husserls. Springer.

Melle, U. (1990). Objektivierende und nicht-objektivierende Akte. In S. Ijsseling (Ed.), Husserl-Ausgabe und Husserl-Forschung (pp. 35-49). Dordrecht: Kluwer Academic Publishers.

Merleau-Ponty, M. (1945). Phénoménologie de la perception. Paris: Gallimard.

Morrison, J. C. (1970). Husserl and Brentano on intentionality. Philosophy and Phenomenological Research, 31(1), 27-46. 
Mulligan, K., \& Smith, B. (1988). Mach and Ehrenfels: the Foundations of Gestalt Theory. In B. Smith (Ed.), Foundations of Gestalt Theory (pp. 124-157). München; Wien: Philosophia Verlag.

Natorp, P. (1888). Einleitung in die Psychologie nach kritischer Methode. Freiburg i. Bg: Mohr.

Rollinger, R. D. (1999). Husserl's Position in the School of Brentano. Springer Science \& Business Media.

Rollinger, R. D. (2004). Austrian Theories of Judgment: Bolzano, Brentano, Meinong, and Husserl. In A. Chrudzimski \& W. Huemer (Eds.), Phenomenology and analysis: Essays in central European philosophy (pp. 257-284). Frankfurt: Ontos Verlag.

Seron, D. (2009). La critique de la psychologie de Natorp dans la Ve Recherche logique de Husserl. Philosophiques, 36(2), 533-558.

Seron, D. (2017). La conscience a-t-elle des parties? In L.-J. Lestocart (Ed.), Esthétique de la complexité: Pour un cognitivisme non linéaire (pp. 23-49). Paris: Hermann.

Smith, B. (2000). Logic and formal ontology. Manuscrito: Revista Internacional de Filosofia, 23(2), 275-324.

Smith, D. W. (2003). The Unity of Husserl's Logical Investigations: Then and Now. In D. Fisette (Ed.), Husserl's Logical Investigations Reconsidered (pp. 21-34). Dordrecht: Springer Netherlands. https://doi.org/10.1007/978-94-017-0207-2_3

Smith, Q. (1977). On Husserl's theory of consciousness in the Fifth Logical Investigation. Philosophy and Phenomenological Research, 37(4), 482-497.

Sokolowski, R. (1968). The logic of parts and wholes in Husserl's investigations. Philosophy and Phenomenological Research, 28(4), 537-553.

Sokolowski, R. (1974). Husserlian meditations: How words present things. Northwestern University Press.

Spiegelberg, H. (1981). "Intention" and "Intentionality" in the Scholastics, Brentano and Husserl. In H. Spiegelberg (Ed.), The Context of the Phenomenological Movement (pp. 3-26). Dordrecht: Springer Netherlands. https://doi.org/10.1007/978-94017-3270-3_1

Sussbauer, A. (1995). Intentionalität, Sachverhalt, Noema: Eine Studie zu Edmund Husserl. München: Alber.

Twardowski, K. (1977). On the Content and Object of Presentations: a Psychological Investigation. Springer Science \& Business Media.

Willard, D. (2003). The Theory of Wholes and Parts and Husserl's Explication of the Possibility of Knowledge in the Logical Investigations. In D. Fisette (Ed.), Husserl's Logical Investigations Reconsidered (pp. 163-181). Dordrecht: Springer.

Winkler, R. (2006). Husserl and Bergson on time and consciousness. In Logos of Phenomenology and Phenomenology of the Logos. Book Three (pp. 93-115). Springer.

Zahavi, D. (2008). Intentionalität und Bewusstsein. In V. Mayer (Ed.), Logische Untersuchungen (pp. 139-158). Berlin: Akademie Verlag. 